\title{
A Study on the Correlation between Bead Geometry and Tensile Strength of Single Lap jointed Dissimilar Combinations through Regression Analysis
}

\section{회귀분석을 이용한 이종조합 필렛 용접부 비드형상과 인장강도간의 상관관계}

Jae Won Kim*, Jae-Hwang Kim**, Kwang-jin Lee**, Sung-Wook Kang***, and Changwook Ji*,

*Advanced Forming Process R\&D Group, Korea Institute of Industrial Technology,

Ulsan Division, 44776, Korea

${ }^{* *}$ Carbon Materials Application R\&D Group, Korea Institute of Industrial Technology, Jeonbuk Division, 54853, Korea

***Precision Mechanical Process and Control R\&D Group, Korea Institute of Industrial Technology, Dongnam Division, 52845, Korea

†Corresponding author: cwji@kitech.re.kr

(Received December 17, 2020; Revised January 18, 2021; Accepted April 2, 2021)

\begin{abstract}
In dissimilar overlap joints that are welded using gas metal arc welding, the shape of the weld bead changes due to changes in welding variables such as current, voltage, speed, and teaching position. The bead shape is a major factor that influences the evaluation of the tensile strength. Thus, it is crucial to control the shape of the bead and produce a bead with an optimal shape. In particular, in the case of a dissimilar combination with a thickness ratio of 4:1, it is difficult to weld all the joint surfaces of the upper plates. The presence of such a non-jointed area can change the tensile strength according to the bonded area. It is expected that a particular value of the critical jointed area satisfies the tensile strength constraints. In this study, various bead shapes were fabricated according to the welding parameters of dissimilar combinations with a thickness ratio of $4: 1$, and the corresponding tensile properties were evaluated. In addition, regression analysis was used to investigate the correlation between the bead shape and tensile strength.
\end{abstract}

Key Words: Regression analysis, Dissimilar combination, Gas metal arc welding, Tensile strength, Bead geometry

\section{Introduction}

For response to recently reinforced environmental regulations, research has been conducted on the development of muffler modules for filtering the exhaust gas inevitably generated by the operation of internal combustion engines. In particular, since diesel engines for heavy machinery have a high degree of exhaust gas pollution depending on the displacement, a diesel particulate filter (DPF) that filters the particulate matter or soot generated by incomplete combustion must be in- stalled in the muffler ${ }^{1}$. DPFs that have been mass-produced or developed thus far were designed to be detachable and attachable using the flange-up method that fastens each part with a clamp. Since most assembly processes in the muffler manufacturing process require welding, however, excellent mechanical properties, such as high tensile and fatigue properties, are required for the welded joint during the design of a muffler module considering the extreme environment and repeated loads of transport equipment ${ }^{2,3)}$. When dissimilar materials with different thicknesses are subjected to lap joint, the access of the welding torch is difficult due 
to the limited work environment, and it is also difficult to secure stability for the quality and mechanical properties of the welded joint due to the complex design structure with a large difference in thickness between the upper and lower materials. In particular, since welding defects including fracture in the welded joint, which cause poor tensile strength, are increasing, it is necessary to derive optimal welding conditions to address such defects ${ }^{4,5)}$. Therefore, this study aimed to derive the optimal welding conditions that satisfy the tensile properties of the single lap jointed dissimilar combination with a thickness ratio of 4:1 for muffler module welding as well as the critical bead geometry for securing excellent weld quality by conducting regression analysis and ANSYS simulation to identify bead geometry factors that affect tensile strength. First, correlations between major weld bead geometry factors and tensile strength were analyzed using regression analysis, and then ANSYS analysis was conducted to verify the relationships between the fracture location and the weld bead geometry factors during the tensile test.

\section{Experimental Method}

\subsection{Experimental materials and equipment}

The dissimilar combination materials used in this study were $8.0 \mathrm{~mm}$-thick $\mathrm{SS} 400$ and $2.0 \mathrm{~mm}$-thick SUS439, which have been used in muffler modules. SF-436 with a diameter of $1.2 \mathrm{~mm}$ was used as a filler for bonding the two plates. Table 1 shows the chemical compositions of the materials and filler used in this study. The welding equipment used in this study was TPS4000 from Fronius, and automated single lap joint was performed using a 6-axis robot. When dissimilar combination welding specimens were prepared, the contact tip to work distance (CTWD) was fixed at 15 $\mathrm{mm}$ and the torch angle at $55^{\circ} .100 \%$ Ar gas was constantly supplied at $20 \mathrm{~L} / \mathrm{min}$ as protective gas. The current, speed, and teaching position (T.P) were only selected as welding parameters. Fig. 1 shows the arc welding equipment for the experiment. To derive the optimal welding conditions, welding conditions were set using the current and speed values within the $\pm 15 \%$

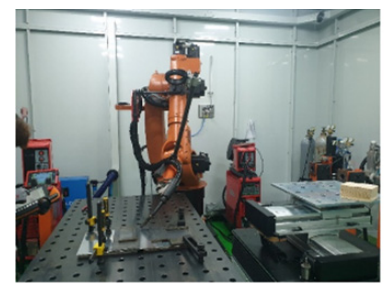

(a) Robot and MIG machine

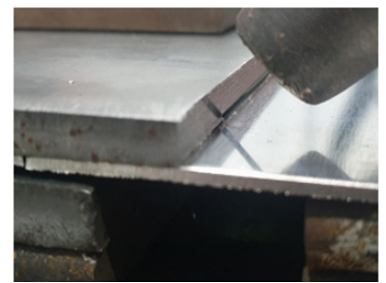

(c) Teaching position

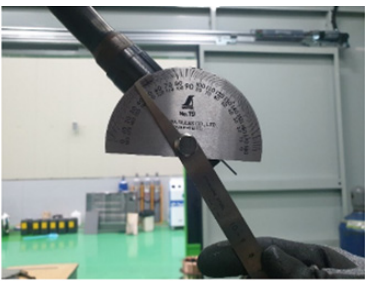

(b) Torch angle

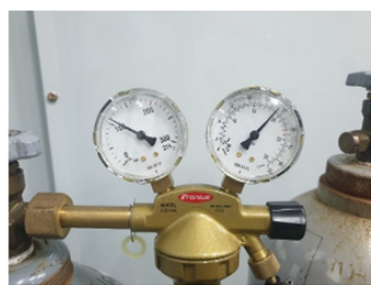

(d) Shielding gas flow
Fig. 1 Welding device set-up for the experiment
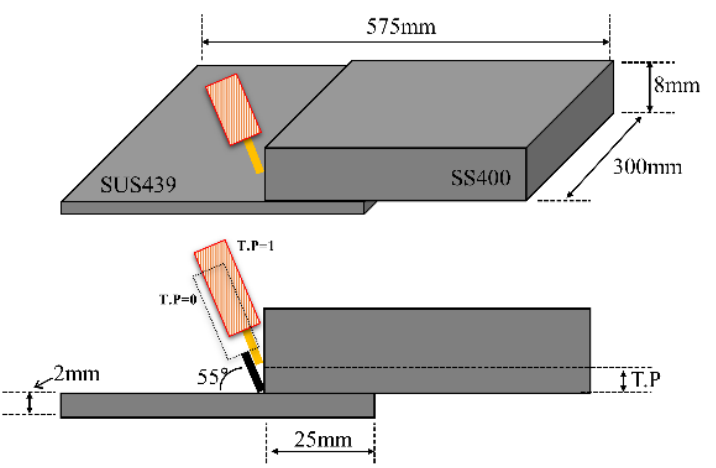

Fig. 2 Specification of lap joint welding specimen

range under the single lap joint conditions used in the field. Fig. 2 shows the dimensions of the plates for single lap joint and the location of T.P. T.P was moved in the thickness direction of the upper plate to secure the proper bonded area of the thick upper plate. The T.P $=0$ condition represents that the teaching of the wire is applied to the location where the upper and bottom plates are bonded, whereas the T.P $=1$ condition indicates that the teaching of the welding torch is lifted by $1 \mathrm{~mm}$ in the thickness direction of the upper plate from the bottom plate surface. In this study, 18 welding condition combinations created by combining the current, speed, and T.P conditions were used to obtain the weld bead geometry as shown in Table 2.

Table 1 Chemical compositions of used material and welding wire (wt. \%)

\begin{tabular}{|c|c|c|c|c|c|c|c|c|}
\hline & $\mathrm{C}$ & $\mathrm{Si}$ & $\mathrm{Mn}$ & $\mathrm{P}$ & $\mathrm{S}$ & $\mathrm{Cr}$ & $\mathrm{Mo}$ & $\mathrm{Ti}$ \\
\hline SUS439(Bottom) & $<0.12$ & $<0.75$ & $<1.0$ & $<0.04$ & $<0.03$ & $16-18$ & & \\
\hline SS400(Upper) & 0.18 & 0.14 & 0.54 & 0.050 & 0.050 & & & \\
\hline SF-436(Filler) & 0.03 & 0.60 & 0.40 & 0.008 & 0.010 & 16.8 & 0.78 & 0.45 \\
\hline
\end{tabular}


Table 2 Variable for experimental design

\begin{tabular}{|c|c|c|c|}
\hline & Level (-) & Level $(0)$ & Level $(+)$ \\
\hline $\begin{array}{c}\text { Teaching position } \\
(\mathrm{mm})\end{array}$ & 0 & 1 & 1 \\
\hline Current (A) & 140 & 155 & 170 \\
\hline Speed (mm/s) & 7 & 9 & 11 \\
\hline
\end{tabular}

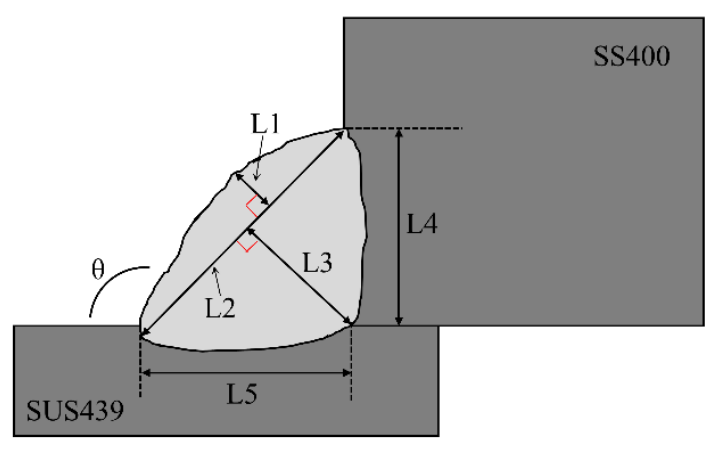

$\mathrm{L} 1=$ the beat height

$\mathrm{L} 2=$ the distance between the lower and upper plate

L3 = effective throat thickness

$\mathrm{L} 4=$ the distance between the upper plate and the weld root

$\mathrm{L} 5=$ the leg length

$\Theta=$ Toe angle

Fig. 3 Nomenclature of the weld bead

\subsection{Tensile strength evaluation and bead cross- section analysis}

As for arc welding for the tensile test and weld bead geometry analysis, single lap joint was performed after overlapping $300 \times 300 \mathrm{~mm}$ materials by $25 \mathrm{~mm}$ as shown in Fig. 2. For the shear tensile test, specimens were prepared in accordance with KS B 0802(2003), and then the test was repeated four times under each welding condition. The final fracture location was defined as the location where fracture occurred three times or more after the tensile test. For the weld bead cross-section analysis, the welded joint collected from the center of the specimen under each welding condition was precisely cut and polished with sandpaper, and then observed using a microscope after 3\% nital etching $\left(\mathrm{HNO}_{3} 3 \mathrm{~mL}+\right.$ ethic alcohol $\left.97 \mathrm{~mL}\right)$. Fig. 3 shows geometry factors for the bead cross-section geometry that varies depending on the welding parameters in single lap joint ${ }^{7,8)}$. The dimensions of the selected geometry factors were captured using a microscope, and then the Image-Pro plus software was used.

\subsection{Regression analysis}

Regression analysis refers to a statistical analysis method in which a mathematical model is assumed to identify the effects of independent variables on dependent variables, and this model is predicted from the data of the measured variables ${ }^{9}$. The regression analysis used in this study utilized MINITAB 19, a statistical analysis software program. The current, speed, and T.P were selected as independent variables that affect dependent variables, i.e. the weld bead geometry factors. Main effects plot analysis was also conducted to identify the main factors that affect the six geometry factors (dependent variables) according to the change in the levels of the independent variables ${ }^{10,11}$. The main effects plot is frequently used to identify the effect of one or more categorical factors on the quantitative response. The main effects plot parallel to the $\mathrm{x}$-axis means that there is no effect, and the size of the main effect increases as the slope of the plot increases ${ }^{11)}$. In addition, fitted line plot analysis was conducted among the regression analysis methods to derive the correlation between each dimension of the weld bead geometry and tensile strength. Fitted line plot analysis is suitable for expressing the relationship between a quantitative predictor and response, and its result is determined valid when $\mathrm{R}^{2}$ is $95 \%$ or higher or when the P-value is 0.05 or less ${ }^{10}$. Since the value of $\mathrm{R}^{2}$ increases as the number of variables and the amount of data increase ${ }^{11,12)}$, it was excluded in terms of judgment in this study.

\subsection{ANSYS simulation}

ANSYS simulation analysis was conducted to examine the correlation between the weld bead geometry and tensile strength based on the results derived through an actual experiment. The boundary condition was set, in which the filler is bonded to the upper and bottom plates. As for load conditions, under the condition that the bottom plate was fixed, when the opposite surface of the fixed part was moved by the enforced displacement in the $\mathrm{X}$-axis direction using the displacement condition, the displacement value that reached the maximum tensile strength of the upper plate, bottom plate, and filler was examined and the condition that exceeded the ultimate tensile strength (UTS) at the shortest displacement was predicted as a fracture location. During the analysis, the $\mathrm{Y}$ - and $\mathrm{Z}$-axis values were set to zero to assume that there was no movement except in the $\mathrm{X}$-axis direction, and the occurrence of bending deformation due to the thickness ratio (4:1) was prevented using the stack. Fig. 4 and Table 3 show the schematic of the tensile specimen and the properties of the materials used for the analysis. 


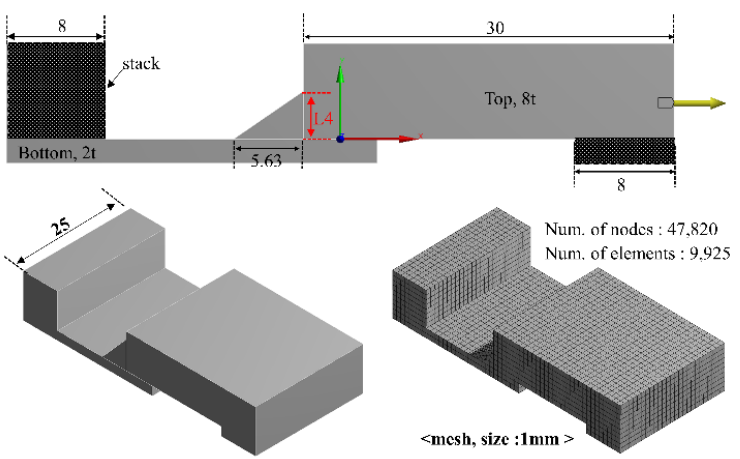

Fig. 4 Schematic of tensile specimen and mesh for ANSYS simulation

Table 3 Value of material physical properties for ANSYS simulation

\begin{tabular}{|c|c|c|c|}
\hline & $\begin{array}{c}\text { SF-436 } \\
\text { (Filler) }\end{array}$ & $\begin{array}{c}\text { SS400 } \\
\text { (Upper) }\end{array}$ & $\begin{array}{c}\text { SUS439 } \\
\text { (Bottom) }\end{array}$ \\
\hline Density $\left(\mathrm{kg} / \mathrm{m}^{3}\right)$ & 7800 & 7850 & 7695 \\
\hline $\begin{array}{c}\text { Tensile strength } \\
(\mathrm{MPa})\end{array}$ & 392 & 400 & 455 \\
\hline $\begin{array}{c}\text { Young's modulus } \\
(\mathrm{GPa})\end{array}$ & 200 & 210 & 193 \\
\hline Poisson's ratio & 0.3 & 0.3 & 0.29 \\
\hline
\end{tabular}

\section{Experiment Results and Discussion}

\subsection{Analysis of bead geometry factors for single lap joint}

Fig. 5 shows the cross-section bead geometry obtained by performing welding under the conditions in Table 2 . Regardless of T.P, when the current was 140 A, a humping bead, which is the condition of insufficient penetration, was observed in the weld speed range used in the experiment. When it was $155 \mathrm{~A}$, a humping bead was observed only at a high speed of $11 \mathrm{~mm} / \mathrm{s}$. Except for the conditions in which a humping bead was gen-

\begin{tabular}{|c|c|c|c|}
\hline $\begin{array}{c}\text { Speed } \\
\text { Current }\end{array}$ & 7 & 9 & 11 \\
\hline 140 & $\begin{array}{c}\text { Hunping } \\
\text { bead }\end{array}$ & $\begin{array}{c}\text { Hunping } \\
\text { bead }\end{array}$ & $\begin{array}{c}\text { Hunping } \\
\text { bead }\end{array}$ \\
\hline 155 & & & $\begin{array}{c}\text { Hunping } \\
\text { bead }\end{array}$ \\
\hline 170 & & & \\
\hline
\end{tabular}

(a) Teaching position $=1$ erated, excellent bead geometry was obtained in all combinations of welding conditions. It was observed, however, that not all the areas of the upper plate SS400 with a thickness of $8 \mathrm{t}$ were bonded in the thickness direction. It appears that some non-jointed areas existed in the upper plate because the welding condition was selected to prevent burn through by overheating, which occurs in the relatively thin bottom plate when trying the penetration of the area in the thickness direction of the upper plate in the plate combination with a thickness ratio of $4: 1^{12)}$. Table 4 shows the results of measuring the dimensions of the bead geometry factors for excellent welds shown in Fig. 3, excluding welding conditions that exhibited humping beads (measurement locations: L1-L5, $\theta$ ).

For ten welding condition cases with excellent welds, which were determined through the observation of the weld bead geometry in Fig. 5, the tensile strength of the welded joint and the fracture location after the tensile test are shown in Table 5. As for the fracture location expressed in Table 5, the base metal (B.M) fracture means the fracture that occurred in the bottom SUS439 material, and the weld metal (W.M) fracture was defined as the fracture that occurred at the boundary between the filler and the upper plate of SS400 as shown in Fig. 6. As can be seen from the table, for cases 1 to 5 $(\mathrm{T} . \mathrm{P}=1)$, fracture mostly occurred in B.M except for case 2 , and the tensile strength was $410 \mathrm{MPa}$ or higher. In some experiment results, W.M fracture was observed, and the tensile strength ranged from 330 to 400 $\mathrm{MPa}$, which were slightly lower compared to the tensile strength values obtained when B.M fracture occurred. For cases 6 to 10 (T.P=0), on the other hand, fracture mostly occurred in W.M and the tensile strength ranged from 200 to $300 \mathrm{MPa}$, which were significantly lower compared to the tensile strength obtained when B.M fracture occurred.

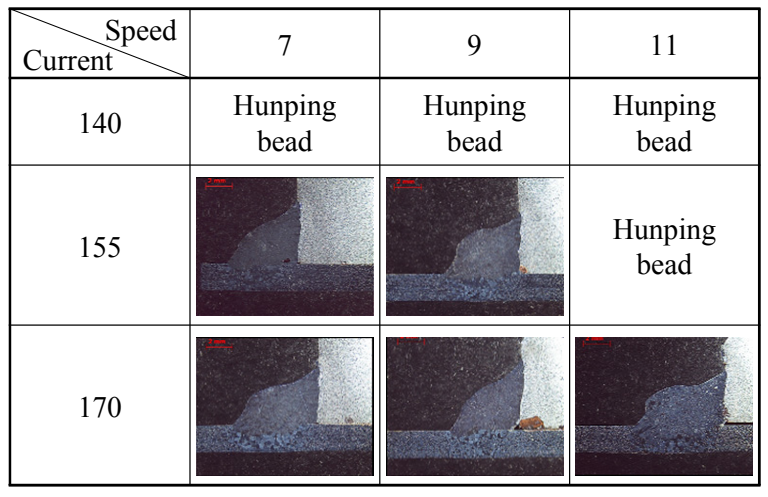

(b) Teaching position $=0$

Fig. 5 Results of cross-section bead geometry for MIG welded dissimilar combination, (a) T.P = 1, (b) T.P = 0 
A Study on the Correlation between Bead Geometry and Tensile Strength of Single Lap jointed Dissimilar Combinations through Regression Analysis

Table 4 Results of dimension for bead geometry according to welding parameters

\begin{tabular}{|c|c|c|c|c|c|c|c|c|c|}
\hline \multirow{2}{*}{ Case No. } & \multicolumn{3}{|c|}{ Welding parameter } & \multicolumn{5}{c|}{ Bead geometry } \\
\cline { 2 - 11 } & Current & Speed & $\begin{array}{c}\text { Teaching } \\
\text { position }\end{array}$ & L1 & L2 & L3 & L4 & L5 & $\Theta$ \\
\hline 1 & 155 & 7 & 1 & 2.01 & 7.01 & 3.34 & 5.51 & 4.24 & 102.3 \\
\hline 2 & 155 & 9 & 1 & 0.89 & 7.66 & 3.65 & 4.69 & 6.03 & 134.1 \\
\hline 3 & 170 & 7 & 1 & 0.32 & 7.85 & 3.87 & 5.76 & 5.28 & 131.1 \\
\hline 4 & 170 & 9 & 1 & 0.62 & 8.05 & 3.88 & 5.47 & 5.71 & 131.1 \\
\hline 5 & 170 & 11 & 1 & 0.48 & 8.77 & 4.13 & 6.30 & 5.69 & 121.9 \\
\hline 6 & 155 & 7 & 0 & 0.60 & 6.96 & 3.49 & 4.56 & 5.36 & 125.9 \\
\hline 7 & 155 & 9 & 0 & 1.03 & 7.23 & 3.43 & 4.52 & 5.55 & 112.6 \\
\hline 8 & 170 & 7 & 0 & 0.85 & 8.30 & 3.79 & 4.82 & 6.53 & 134.2 \\
\hline 9 & 170 & 9 & 0 & 0.59 & 7.57 & 3.65 & 5.12 & 5.36 & 129.0 \\
\hline 10 & 170 & 11 & 0 & 1.20 & 7.94 & 3.35 & 4.03 & 6.60 & 121.6 \\
\hline
\end{tabular}

Table 5 Results of tensile strength and fracture location

\begin{tabular}{|c|c|c|c|c|c|c|c|c|c|c|c|}
\hline \multirow{3}{*}{\begin{tabular}{|c|} 
Case No. \\
1
\end{tabular}} & \multicolumn{3}{|c|}{ Welding parameter } & \multicolumn{8}{|c|}{ Tensile strength (MPa) / Fracture location } \\
\hline & Current & Speed & $\begin{array}{l}\text { Teaching } \\
\text { position }\end{array}$ & \multicolumn{2}{|c|}{ Test 1} & \multicolumn{2}{|c|}{ Test 2} & \multicolumn{2}{|c|}{ Test 3} & \multicolumn{2}{|c|}{ Test 4} \\
\hline & 155 & 7 & \multirow{5}{*}{1} & 419 & B.M & 420 & B.M & 420 & B.M & 417 & B.M \\
\hline 2 & 155 & 9 & & 330 & W.M & 353 & W.M & 378 & W.M & 345 & W.M \\
\hline 3 & 170 & 7 & & 428 & B.M & 423 & W.M & 427 & B.M & 427 & B.M \\
\hline 4 & 170 & 9 & & 419 & B.M & 420 & B.M & 419 & B.M & 360 & W.M \\
\hline 5 & 170 & 11 & & 418 & B.M & 420 & B.M & 409 & B.M & 337 & W.M \\
\hline 6 & 155 & 7 & \multirow{5}{*}{0} & 275 & W.M & 286 & W.M & 377 & W.M & 307 & W.M \\
\hline 7 & 155 & 9 & & 235 & W.M & 288 & W.M & 267 & W.M & 314 & W.M \\
\hline 8 & 170 & 7 & & 422 & B.M & 401 & W.M & 312 & W.M & 306 & W.M \\
\hline 9 & 170 & 9 & & 427 & W.M & 368 & W.M & 336 & W.M & 361 & W.M \\
\hline 10 & 170 & 11 & & 279 & W.M & 310 & W.M & 255 & W.M & 391 & W.M \\
\hline
\end{tabular}

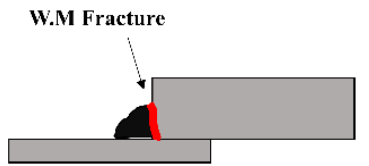

(a)

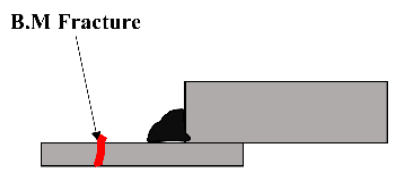

(b)
Fig. 6 Schematic of fracture location after tensile strength test, (a) weld metal fracture, (b) base metal fracture

As for main factors that affect the tensile strength of the welded joint during arc welding, the bead geometry is a representative factor and the bonded area is known to have a direct impact ${ }^{13,14)}$. The results of Fig. 5 and Table 5 indicate that the fracture location and tensile strength vary depending on T.P among the other welding parameters. In the case of the welding conditions that caused W.M fracture, fracture occurred at the interface between SS400 and filler. This indicates that L4 in
Table 4, which represents the length of the bonded area between SS400 and filler, can have an influence among the other bead geometry factors. L5, which is the length of the bonded area between SUS439 and filler, is also judged to be a main factor that affects the tensile strength, but its value was mostly equal to or higher than that of L4, indicating that fracture mostly occurred at the interface between SS400 and filler. When the conditions that caused fracture and the L4 value were compared through the results in Tables 4 and 5, it was found that the length of L4 was higher than $5.5 \mathrm{~mm}$. B.M fracture or W.M fracture occurred when L4 was higher than $4.8 \mathrm{~mm}$, and W.M fracture occurred when it was lower than 4.8. In other words, it appears that B.M fracture may occur rather than W.M fracture when the length of L4 is higher than $68 \%$ of the thickness of the upper base metal $(8 \mathrm{~mm})$. From section 3.2 , an attempt was made to identify welding parameters that determine 
the bead geometry factors through basic linear regression analysis using the values of the bead geometry factors obtained from the experiment and to examine the relationship among the tensile strength, fracture location, and bead geometry factors obtained through this study.

\subsection{Correlation derivation through regression analysis}

First, the results of the main effects plot analysis are shown in Fig. 7 to identify the welding parameters (independent variables) that affect the dimension of each weld bead geometry factor. Under the experimental conditions of this study, most of the weld bead dimensions tended to be proportional or inversely proportional to the current or speed. It was confirmed, however, that L4 is affected by T.P rather than the current and speed. It was also observed that the length of L4 showed a tendency to increase as T.P was lifted by 1 $\mathrm{mm}$ in the thickness direction of the upper plate from the bottom plate, and this was in agreement with the results in Table 4. This appears to be because the arc heat source first generated in the upper plate melted the upper plate, and the melt pool flew in the direction of gravity during welding. The other bead geometry factors are judged to be more affected by the current or speed than the level of T.P. In general, the main factors that determine the bead geometry are the current and speed, but only L4 was more affected by T.P in this study because T.P by the thickness ratio was selected as a parameter.

Next, the results of the fitted line plot analysisare
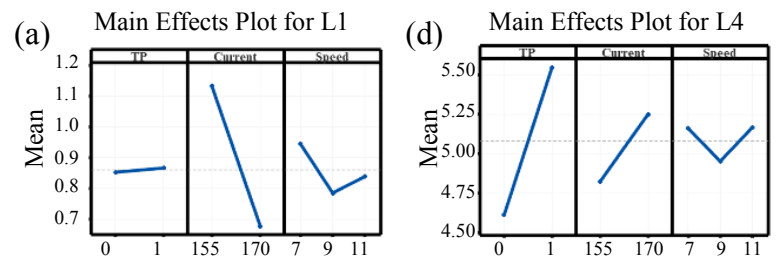

(b) Main Effects Plot for L2

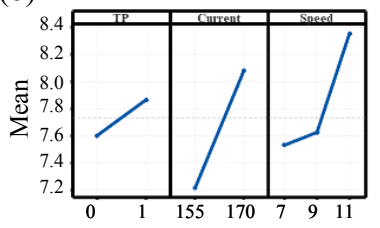

(e) Main Effects Plot for L5
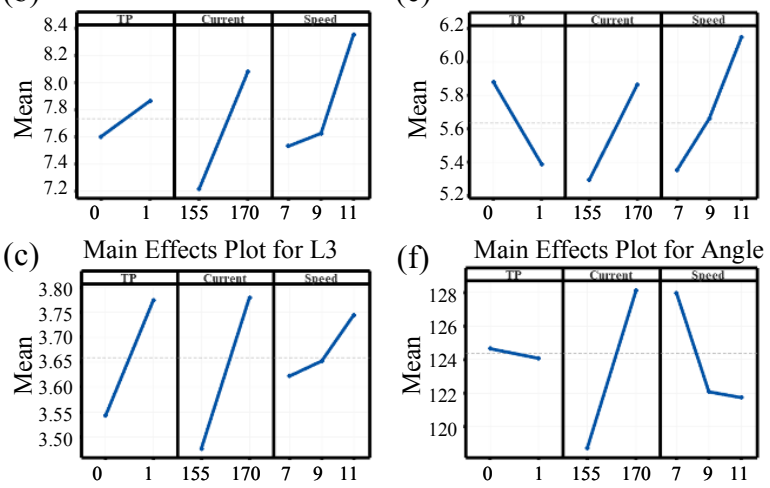

Fig. 7 Main effect of input variable on each dimension of bead geometry, (a) L1, (b) L2, (c) L3, (d) L4, (e) L5, (f) $\Theta$ shown in Fig. 8 to derive the correlations between the weld bead geometry factors and tensile strength. Under the experimental conditions of this study, the correlations between all the dimensions, except for L4, and tensile strength exhibited a P-value of 0.05 or higher, indicating that they are not highly correlated with the change in tensile strength. In the case of L4, the P-value was valid as it was 0.001 , and $\mathrm{R}^{2}$ also showed a high value of more than $75 \%$. This indicates that there is a general linear relationship between L4 and tensile strength. This appears to be because the length of L5 is equal to or higher than that of L4, which are factors that may affect the tensile strength, and thus the influence of L4 is larger as mentioned earlier on the actual weld bead geometry. When the relationship among the weld bead geometry factors, tensile strength, and fracture location was analyzed through regression analysis, it was found that there is a linear relationship between L4 and tensile strength compared to other geometry factors. Through the actual tensile strength results and regression analysis, it was verified that, for the L4, the fracture location started to change at the L4 of $5.6 \mathrm{~mm}$, which corresponds to $68 \%$ of the thickness of the upper base metal $(8 \mathrm{~mm})$. ANSYS analysis was conducted to investigate the reason.

\subsection{Verification of the correlation between the bead and tensile strength through ANSYS analysis}

ANSYS simulation was performed to verify the rela-
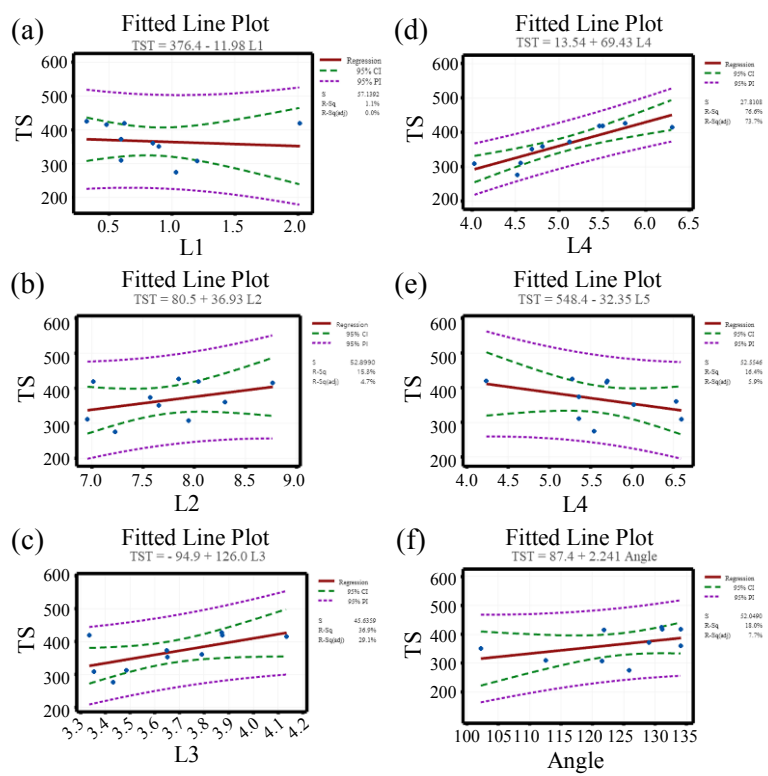

Fig. 8 Fitted line plot of each dimension of bead geometry affected the tensile strength, (a) L1, (b) L2, (c) L3, (d) L4, (e) L5, (f) $\ominus$ 


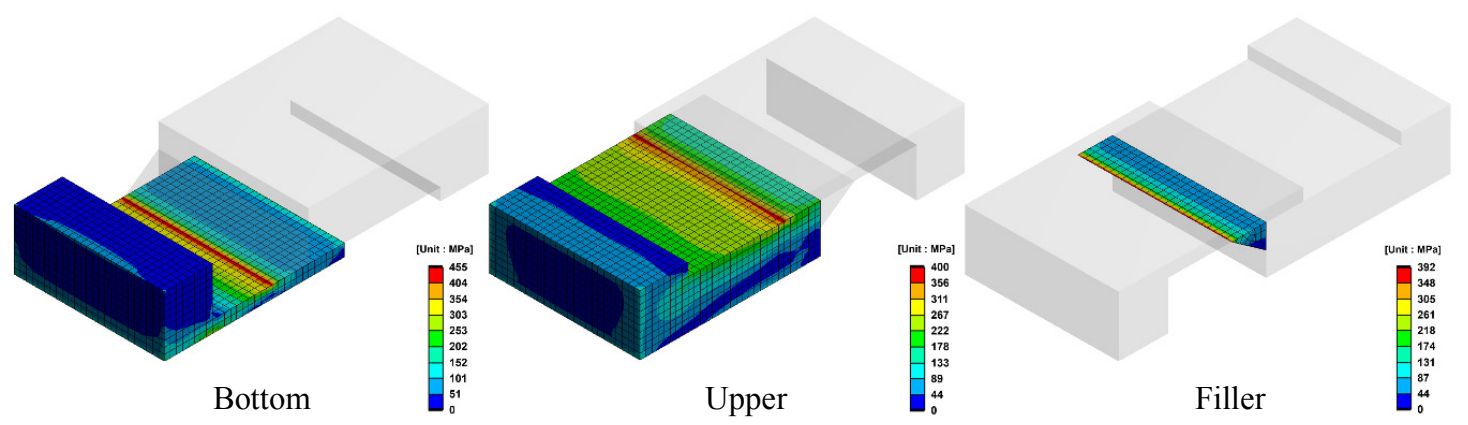

Fig. 9 Representative image of minimum stress and displacement of each material after tensile ANSYS simulation

Table 6 Value and location of minimum displacement for fracture according to changes L4 dimension

\begin{tabular}{|c|c|c|c|c|}
\hline & \multicolumn{2}{|c|}{ Minimum displacement for fracture [mm] } & \multirow{2}{*}{$\begin{array}{c}\text { Initial fracture } \\
\text { location }\end{array}$} \\
\cline { 2 - 4 } & Bottom (SUS 439) & Top (SS400) & Filler (SF-436) & \multirow{2}{*}{ Filler (SF436) } \\
\hline CASE 1 $(\mathrm{L} 4=4.0 \mathrm{~mm})$ & 0.0308 & 0.0663 & 0.0271 & Filler (SF436) \\
\hline CASE 2 $(\mathrm{L} 4=4.8 \mathrm{~mm})$ & 0.0303 & 0.0667 & 0.0280 & Bottom (SUS 439) \\
\hline CASE 3 $(\mathrm{L} 4=5.6 \mathrm{~mm})$ & 0.0299 & 0.0671 & 0.0302 & Bottom (SUS 439) \\
\hline CASE 4 $(\mathrm{L} 4=6.4 \mathrm{~mm})$ & 0.0297 & 0.0674 & 0.0312 & \\
\hline
\end{tabular}

tionship among the tensile strength, fracture location, and L4, among the other bead geometry factors. For the simulation, only the L4 length was set as a variable, and a total of four cases were selected from 4 to 6.4 $\mathrm{mm}$ at $0.8 \mathrm{~mm}$ intervals. The other weld bead geometry factors were fixed. Fig. 9 and Table 6 show the fracture location according to the change in L4 obtained using ANSYS simulation. For the bottom plate, the tensile strength reached the UTS of the bottom plate (455 $\mathrm{MPa}$ ) when the displacement was $0.03 \mathrm{~mm}$ or higher for cases 1 and 2 and when it was lower than $0.03 \mathrm{~mm}$ for cases 3 and 4 . For the upper plate, UTS was reached when the displacement of $0.06 \mathrm{~mm}$ occurred for all cases. In the case of the filler, its UTS (392 MPa) was reached when the displacement was less than $0.03 \mathrm{~mm}$ for cases 1 and 2 and when it exceeded $0.03 \mathrm{~mm}$ for cases 3 and 4 . These results confirmed that the shortest displacement was exhibited at the filler for cases 1 and 2 and at the bottom plate for cases 3 and 4 . In other words, it can be judged that fracture first occurs in the filler for cases 1 and 2 where L4 is $4.8 \mathrm{~mm}$ or less and in the bottom plate for cases 3 and 4 where L 4 is 5.6 $\mathrm{mm}$ or higher. When the relationship among the L4 length, tensile strength, and fracture location was examined through ANSYS analysis, it was found that W.M fracture occurred when L4 was $4.8 \mathrm{~mm}$ or less and B.M fracture when L4 was $5.6 \mathrm{~mm}$ or higher. This indicates that the critical L4 length is between 4.8 and $5.6 \mathrm{~mm}$.

\section{Conclusion}

For the metal inert gas (MIG) welding of the SS400 (8t) and SUS 439 (2t) dissimilar combination with a thickness ratio of $4: 1$, the correlation between the weld bead and tensile strength was examined through regression analysis and ANSYS analysis in this study. The results are as follows.

1) When the teaching position (T.P) was $1 \mathrm{~mm}$ from the bottom plate, conditions that satisfied more than $400 \mathrm{MPa}$ were derived. When T.P was zero, fracture occurred in the weld metal (W.M) and the tensile strength was not satisfied.

2) As for regression analysis to examine the correlation between the L4 length and tensile strength, it was confirmed through the main effects plot that the L4 length, among the bead geometry factors, is most affected by the change in T.P. The results of fitted line plot analysis also confirmed that the change in L4 has the largest impact on the change in tensile strength.

3) When the relationship among the L4 length, tensile strength, and fracture location was examined through ANSYS analysis, it was found that W.M fracture occurred when L4 was $4.8 \mathrm{~mm}$ or less and base metal (B.M) fracture when L4 was $5.6 \mathrm{~mm}$ or higher. Based on this, it is judged that the critical L4 length for the change in fracture location is between 4.8 and $5.6 \mathrm{~mm}$. 


\section{Acknowledgement}

This research was supported by the Wide-Area Industrial Promotion Program (NK200035) funded by the government (Ministry of Trade, Industry and Energy) in 2020 .

ORCID: Jae Won Km: https://orcid.org/0000-0001-6984-3282 ORCID: Changwook Ji: http://orcid.org/0000-0002-5158-5243

\section{Reference}

1. M. K. Khair, A Review of Diesel Particulate Filter Technologies, SAE Technical Paper Series (2003). https://doi.org/10.4271/2003-01-2303

2. K. Kimapong, S. Triwanapong, Influence of Gas Metal Arc Welding Parameter on Lap Joint Properties of SS400 Carbon Steel and SUS304 Stainless Steel, Key Eng. Mater. 789 (2018) 110-114.

http://doi:10.4028/www.scientific.net/kem.789.110

3. N. Arivazhagan, S. Singh, S. Prakash, and G. M. Reddy, Investigation on AISI 304 austenitic stainless steel to AISI 4140 low alloy steel dissimilar joint by gas tungsten arc, electron beam and friction welding, Mater. Des. 32 (2011) 3036-3050.

4. S. Wang, Q. Ma, and Y. Li, Characterization of microstructure, mechanical properties and corrosion resistance of dissimilar welded joint between 2205 duplex stainless steel and 16MnR, Mater. Des. 32 (2011) 831-837.

5. I. Hajiannia, M. Shamanian, and M. Kasiri, Microstructure and mechanical properties of AISI 347 stainless steel/ A335 low alloy steel dissimilar joint produced by gas tungsten arc welding, Mater. Des. 50 (2013) 566-573.

6. KS B 0802, Method of tensile test for metallic materials, Korea Standard (KS) (2003).
7. I. Hwang, D. Y. Kim, G. Jeong, M. Kang, D. Kim, and Y. M. Kim, Effect of Weld Bead Shape on the Fatigue Behavior of GMAW Lap Fillet Joint in GA $590 \mathrm{MPa}$ Steel Sheets, Met. 7 (2017) 399-410. https://doi.org/10.3390/met7100399

8. D. Y. Kim, I. Hwang, G. Jeong, M. Kang, D. Kim, J. Seo, and Y. M. Kim, Effect of Porosity on the Fatigue Behavior of Gas Metal Arc Welding Lap Fillet Joint in GA 590 MPa Steel Sheets, Met. 8 (2018) 241-253. https://doi.org/10.3390/met8040241

9. J. S. Jung, H. K. Lee, and Y. W. Park, Prediction of Tensile Strength for Plasma-MIG Hybrid Welding Using Statistical Regression Model and Neural Network Algorithm, J. Weld. Join. 34(2) (2016) 67-72. https://doi.org/10.5781/JWJ.2016.34.2.67

10. S. H. Jung, D. Y. Lee, B. U. Kim, and M. K. Lee, A Study for TIG Welding Optimization on Bead Shape of A6061 Alloy Sheet Using DOE, J. Weld. Join. 36(3) (2018) 31-37. https://doi.org/10.5781/JWJ.2018.36.3.5

11. S. W Lee and J. W. Kim, Selecting Optimum Conditions for SPR Processing of High Tension Plates and Aluminum Sheets Using Response Surface Methodology, J. Weld. Join. 37(4) (2019) 339-346. https://doi.org/10.5781/JWJ.2019.37.4.8

12. D. H. Choi and J. H. Shin, Weld Shape Analysis using Central Composite Design in the Laser Welding of Aluminum Alloys, J. Weld. Join. 38(5) (2020) 502-507. https://doi.org/10.5781/JWJ.2020.38.5.10

13. M. P. Groover, Fundamentals of Modern Manufacturing: Materials, Processes, and Systems, 3ed., John Willey \& Sons (Asia) Pte. Ltd., Singapore (2007).

14. J. W. Kim, N. H. Kang, Y. D. Park, D. C. Kim, and M. J. Kang, Effect of Strength Grades of Dual Phase Steels on Failure Location and Joint Efficiency of GMAW Lap Joints, Korean J. Met. Mater. 52(4) (2014) 319-326. https://doi.org/10.3365/KJMM.2014.52.4.319 


\title{
회귀분석을 이용한 이종조합 필렛 용접부 비드형상과 인장강도간의 상관관계
}

\section{A Study on the Correlation between Bead Geometry and Tensile Strength of Single Lap Jointed Dissimilar Combinations through Regression Analysis}

\author{
김재원 ${ }^{*}$ - 김재황** - 이광진 ${ }^{* *}$ - 강성욱 *** - 지창욱 ${ }^{*,+}$ \\ *한국생산기술연구원 울산본부 첨단정형공정연구그룹 \\ **한국생산기술연구원 전북본부 탄소소재응용연구그룹 \\ ***한국생산기술연구원 동남본부 정밀기계공정제어연구그룹
}

1. 서 론

최근 강화되는 환경규제에 대응하기 위한 방안으로 내연기관의 작동과정에서 필연적으로 발생하는 배기가 스를 여과하는 머플러 모듈 개발 연구가 꾸준히 이루어 지고 있다. 특히 중장비용 디젤기관은 배기량에 따른 배출가스 오염도가 높아 불완전 연소에 의해 발생하는 미 세먼지 또는 매연을 걸러내는 디젤필터 트랩장치(Diesel Particulate Filter: DPF)를 반드시 머플러에 장착해 야 한다 ${ }^{1)}$. 지금까지 양산 또는 개발된 $\mathrm{DPF}$ 는 각 부위 를 클램프로 체결하는 플랜지업(flange-up) 방식을 적 용하여 탈·부착이 가능하도록 설계되었으며, 머플러 제 작공정 중 대부분의 조립공정은 용접으로 이루어지기 때문에 머플러 모듈 설계 시 수송기기의 극한 환경 및 반복된 부하를 고려하여 용접부의 높은 인장 및 피로 특성 등의 우수한 기계적 물성이 요구된다 ${ }^{2,3)}$. 그러나 두께가 서로 다른 이종소재를 필렛 용접(lap joint)할 경우 제한적인 작업환경에 의해서 용접 토치의 접근이 어려우며, 상-하부 소재간의 두께 비 차이가 큰 복잡 한 설계구조로 인하여 용접 후 용접부 품질 및 기계적 물성에 대한 안정성 확보에 어려움이 있다. 특히 인장 강도를 만족하지 못하고 용접부에서 파단이 발생하는 용접 불량이 증가하고 있는 실정이기 때문에 이를 해결
하기 위한 최적 용접조건 도출이 필요하다 ${ }^{4,5)}$. 따라서 본 연구에서는 머플러 모듈 용접 중 두께 비(ratio of thickness)가 4:1 인 이종 소재의 겹치기 용접부 인 장 특성을 만족하는 최적용접조건을 도출하고 인장강도 값에 미치는 비드 형상인자을 알아보기 위하여 회귀분 석(regression analysis)과 ANSYS 시뮬레이션을 수 행하여 양호한 용접부 품질 확보를 위한 임계 비드 형 상을 도출하고자 하였다. 먼저 회귀분석을 활용하여 인 장강도에 영향을 끼치는 주요 용접부 비드 형상인자를 분석하고 상관관계를 확인하고 그 후 ANSYS 해석을 통해 인장시험 시 파단위치와 용접부 비드 형상인자간 의 관계를 검증하고자 하였다.

\section{2. 실험방법}

\section{1 실험재료 및 장비}

본 실험에 사용된 이종조합 재료는 머플러 모듈에 사 용되고 있는 두께 $8.0 \mathrm{~mm}$ 인 SS400과 $2.0 \mathrm{~mm}$ 인 SUS439이며, 두 판재를 접합하기 위한 용접재료는 직 경 $1.2 \mathrm{~mm}$ 의 SF-436을 사용하였고 실험에 사용된 소재 및 용접재료의 화학조성을 Table 1에 나타내었다. 실험에 사용된 용접장비는 Fronius社의 TPS4000이며, 6축 로봇을 이용한 자동화 겹치기 필렛 용접(single lap joint)을 실시하였다. 이종조합 용접 시험편 제작 시

Table 1 Chemical compositions of used material and welding wire (wt. \%)

\begin{tabular}{|c|c|c|c|c|c|c|c|c|}
\hline & $\mathrm{C}$ & $\mathrm{Si}$ & $\mathrm{Mn}$ & $\mathrm{P}$ & $\mathrm{S}$ & $\mathrm{Cr}$ & $\mathrm{Mo}$ & $\mathrm{Ti}$ \\
\hline SUS439(Bottom) & $<0.12$ & $<0.75$ & $<1.0$ & $<0.04$ & $<0.03$ & $16-18$ & & \\
\hline SS400(Upper) & 0.18 & 0.14 & 0.54 & 0.050 & 0.050 & & & \\
\hline SF-436(Filler) & 0.03 & 0.60 & 0.40 & 0.008 & 0.010 & 16.8 & 0.78 & 0.45 \\
\hline
\end{tabular}




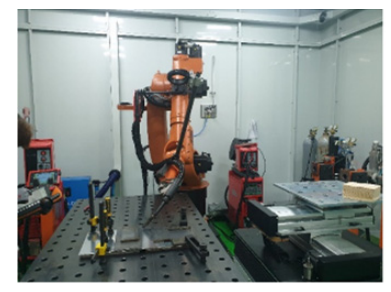

(a) Robot and MIG machine

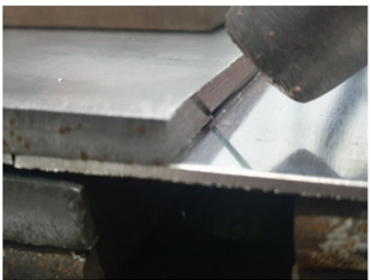

(c) Teaching position

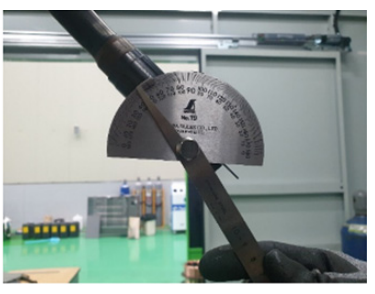

(b) Torch angle

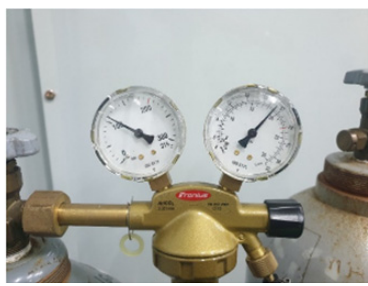

(d) Shielding gas flow
Fig. 1 Welding device set-up for the experiment

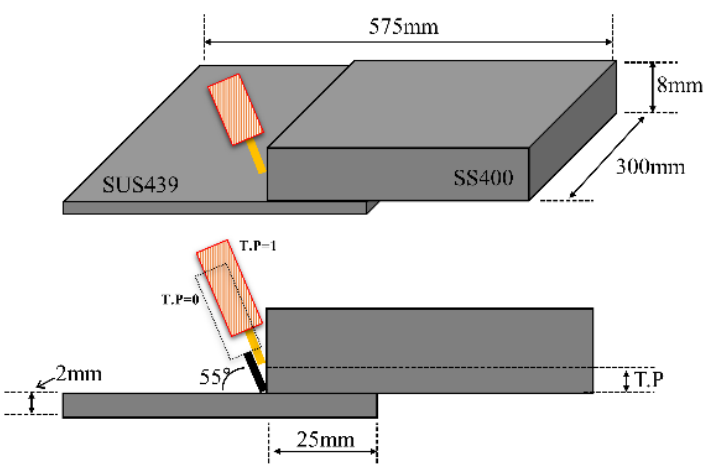

Fig. 2 Specification of lap joint welding specimen

CTWD(contact tip to work distance)는 $15 \mathrm{~mm}$, 토치 각도는 $55^{\circ}$ 로 고정하고 보호가스는 $100 \% \mathrm{Ar}$ 가스를 $20 \mathrm{~L} / \mathrm{min}$ 로 일정하게 공급하였으며, 용접전 류, 용접속도 그리고 티칭 위치(teaching position, 이하 T.P로 표기)만을 변수로 선정하였다. 실험을 위 한 아크 용접 장비 외관은 Fig. 1에 나타내었다. 최적 용접조건 도출을 위한 용접조건 설정은 실제 현장에서 활용되고 있는 겹치기 용접조건에서 $\pm 15 \%$ 수준의 용 접전류와 용접속도 값으로 하였다. Fig. 2는 겹치기 용접부 판재 치수 및 티칭 위치를 나타낸 것이다. 두꺼 운 상부판재의 양호한 접합 면적 확보를 위해 T.P를 상부판재 두께방향으로 이동시켰으며, T.P가 0인 조건 은 상, 하부 판재가 접합되는 위치에 와이어가 티칭된 상태를 의미하며 T.P가 1 인 경우는 하부 판재 표면에 서 상부판재 두께방향으로 $1 \mathrm{~mm}$ 간격을 띄워 용접 토 치를 티칭한 상태를 의미한다. 본 연구에서 용접부 비 드 형상 확보를 위해 활용된 용접조건 조합은 Table 2 에 나타낸 것처럼 용접전류, 용접속도, T.P를 각각 조 합하여 총 18 개의 용접 조합을 수행하였다.
Table 2 Variable for experimental design

\begin{tabular}{|c|c|c|c|}
\hline & Level (-) & Level $(0)$ & Level $(+)$ \\
\hline $\begin{array}{c}\text { Teaching position } \\
(\mathrm{mm})\end{array}$ & 0 & 155 & 1 \\
\hline Current (A) & 140 & 170 \\
\hline Speed (mm/s) & 7 & 9 & 11 \\
\hline
\end{tabular}

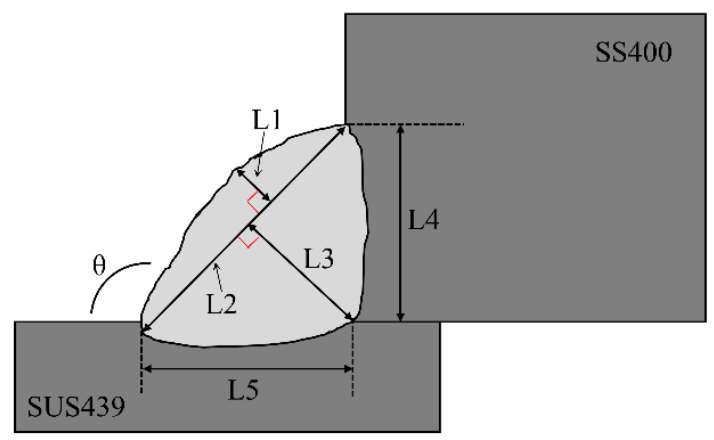

$\mathrm{L} 1=$ the beat height

$\mathrm{L} 2$ = the distance between the lower and upper plate

L3 $=$ effective throat thickness

L4 $=$ the distance between the upper plate and the weld root

$\mathrm{L} 5=$ the leg length

$\Theta=$ Toe angle

Fig. 3 Nomenclature of the weld bead

\section{2 인장강도 평가 및 비드 단면분석}

인장시험 및 용접부 비드 형상 분석을 위한 아크 용 접은 Fig. 2와 같이 $300 \mathrm{~mm} \times 300 \mathrm{~mm}$ 사이즈 소 재를 $25 \mathrm{~mm}$ 겹친 후 겹치기 용접(single lap joint) 을 수행하였으며 전단인장시험은 KS B 0802(2003) $)^{6)}$ 을 기준으로 하여 시험편을 제작한 후 각각의 용접조건 별 4회 반복시험을 실시하였다. 최종 파단위치는 인장 시험 후 파단이 3 회 이상 발생한 위치로 정의하였다. 용접부 비드 단면 분석은 용접조건별로 시험편 중앙부 에서 채취한 용접부를 정밀커팅 후 사포로 연마하고 $3 \%$ 나이탈 에칭 $\left(\mathrm{HNO}_{3} 3 \mathrm{~mL}+\right.$ ethic alcohol $\left.97 \mathrm{~mL}\right)$ 하여 실체현미경으로 관찰하였다. 겹치기 용접에서 용 접 변수에 따라 변화하는 비드 단면 형상에 대한 형상 인자를 Fig. 3 에 나타내었다 ${ }^{7.8)}$. 선정된 형상인자의 치 수는 실체현미경으로 촬영 후 Image-Pro plus 프로 그램을 이용하였다.

\section{3 회귀분석}

회귀분석(regression analysis)이란 독립변수가 종 속변수에 영향을 미치는지 규명하고자 수학적 모형을 가정하고, 이 모형을 측정된 변수들의 데이터로부터 예 
측하는 통계 분석 방법을 뜻한다 ${ }^{9)}$. 본 연구에서 사용 한 회귀분석은 통계분석 프로그램인 MINITAB 19를 활용하였으며, 종속변수인 용접 비드 단면 형상인자에 영향을 주는 독립변수는 용접전류, 용접속도, T.P를 선 정하였고, 독립변수의 수준 변화에 따른 6 가지 형상인 자(종속변수)에 영향을 미치는 주요 인자를 확인하기 위해 주효과도 분석을 수행하였다 ${ }^{10,11)}$. 주효과도는 하 나 이상의 범주형 요인이 계량형 반응에 미치는 영향을 확인할 때 많이 활용하고 주효과도 선이 $\mathrm{x}^{-}$축에 평행 한 수평선이면 효과가 없음을 의미하며 선의 기울기가 가파를수록 주효과의 크기가 더 큰 것을 의미한다 ${ }^{11)}$. 또한, 용접부 비드 형상의 각 치수와 인장강도 값의 상 관관계를 도출하기 위해 회귀분석 방법 중 적합선 그림 분석을 수행하였다. 계량형 예측변수와 반응간의 관계 를 표시하기에 적합한 것으로 일반적으로는 $\mathrm{R}^{2}$ 이 95 $\%$ 이상 또한 $\mathrm{P}-$ 값 $(\mathrm{P}-\mathrm{value})$ 이 0.05 이하일 때 그 결 과가 유효함을 의미한다 ${ }^{10)}$. $\mathrm{R}^{2}$ 의 경우는 변수가 많으 면 많아질수록 그리고 데이터의 량이 방대해 질수록 그 수치가 올라가기에 절대적인 수치 ${ }^{11,12)}$ 으로 본 연구에 서는 그 값은 배제하고 판단하였다.

\subsection{ANSYS 시뮬레이션}

실제 실험을 통해 도출된 결과값을 기반으로 용접부 비드 형상과 인장강도간의 상관관계를 확인하기 위해 ANSYS 시뮬레이션 해석을 수행하였다. 경계조건은 용 접부(filler)와 상, 하부 판재가 접합(bonding)되어 있 는 조건으로 설정하였다. 하중조건은 하부판재가 고정 된 조건에서 고정부 반대편 면을 변위(displacement) 조건을 이용하여 X축 방향으로 강제변위 값만큼 이동 함에 따라 상부, 하부, 용접재료의 최대 인장강도를 도 달하는 변위 값을 확인하고 가장 짧은 변위에서 최대 인장강도(UTS)를 넘는 조건을 파단위치로 예측하였 다. 해석 시 $\mathrm{Y}, \mathrm{Z}$ 축 값은 0 으로 하여 $\mathrm{X}$ 축 방향 이외 는 움직이지 않는 것으로 가정하였으며, stack을 활용 하여 두께 비 $(4: 1)$ 차이에 의한 굽힘 변형 발생을 방 지하였다. 해석에 활용된 소재 특성 및 모식도를 Fig. 4와 Table 3에 나타내었다.

\section{3. 실험결과 및 고찰}

\section{1 겹치기 용접 비드 형상인자 분석}

Table 2를 조건으로 용접한 후 용접부 단면 비드 형 상을 Fig. 5에 나타내었다. T.P 변화에 관계없이 용접 전류가 $140 \mathrm{~A}$ 일 때 실험에 사용된 용접속도 범위 안

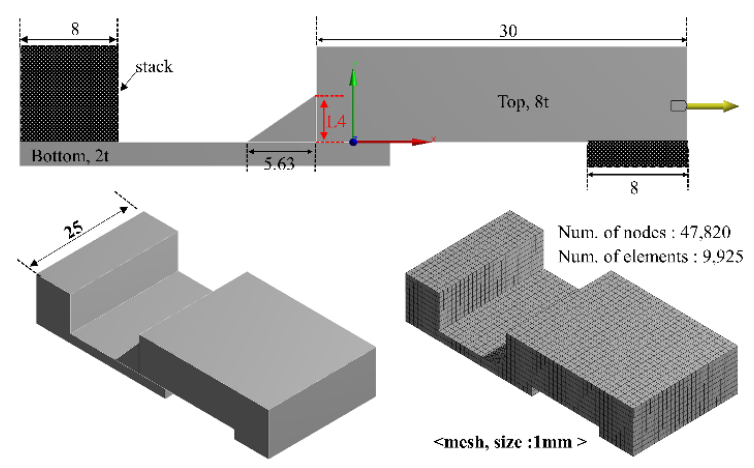

Fig. 4 Schematic of tensile specimen and mesh for ANSYS simulation

Table 3 Value of material physical properties for ANSYS simulation

\begin{tabular}{|c|c|c|c|}
\hline & $\begin{array}{c}\text { SF-436 } \\
\text { (Filler) }\end{array}$ & $\begin{array}{c}\text { SS400 } \\
\text { (Upper) }\end{array}$ & $\begin{array}{c}\text { SUS439 } \\
\text { (Bottom) }\end{array}$ \\
\hline Density $\left(\mathrm{kg} / \mathrm{m}^{3}\right)$ & 7800 & 7850 & 7695 \\
\hline $\begin{array}{c}\text { Tensile strength } \\
(\mathrm{MPa})\end{array}$ & 392 & 400 & 455 \\
\hline $\begin{array}{c}\text { Young's modulus } \\
(\mathrm{GPa})\end{array}$ & 200 & 210 & 193 \\
\hline Poisson's ratio & 0.3 & 0.3 & 0.29 \\
\hline
\end{tabular}

에서는 용입이 불충분한 조건인 험핑비드(humping bead)가 관찰되었으며 $155 \mathrm{~A}$ 조건에서는 용접속도가 빠른 $11 \mathrm{~mm} / \mathrm{s}$ 조건에서만 험핑비드가 관찰되었다. 험핑비드가 발생한 조건 이외에는 모든 용접조건 조합 에서 양호한 비드 형상임을 확인하였으나, 공통적으로 두께가 8t인 상부 판재 $\mathrm{SS} 400$ 은 두께방향으로 모든 면적이 접합되지 않은 것을 관찰하였다. 이는 두께 비 가 4: 1 인 판재 조합에서 상부판재의 두께방향 면적의 용입을 위해서는 상대적으로 두께가 얇은 하부 판재에 과입열에 의한 용락(burn through)발생하게 되는데, 이를 방지하기 위한 조건으로 선정하였기 때문에 상부 판재에서 일부 미접합(non-jointed area)되는 영역이 존재한 것으로 판단된다 ${ }^{12)}$. Table 4는 Fig. 3 의 각 비드 형상인자에 따라 험핑비드가 발생한 용접조건을 제외한 양호한 용접부의 비드 형상인자 별 치수(측정 위치: L1 L5, $\ominus$ )를 측정한 결과이다.

상기 Fig. 5의 용접부 비드 형상 관찰을 통해 결정 된 양호한 용접부를 갖는 10 가지 용접조건 Case에 대 하여 용접부 인장강도 및 인장시험 후 파단위치를 Table 5에 나타내었다. Table 5에 표기한 파단위치는 Fig. 6 에 따라 모재(base metal, B.M)는 하부 SUS439 소 재에서 발생한 파단을 의미하며, 용접부(weld metal, W.M)는 용접부와 상부판재인 SS400의 경계에서 발 
생한 파단으로 정의하였다. 표에서 보는 바와 같이 T.P가 1인 Case $1 \sim 5$ 의 경우 Case 2의 경우를 제 외하고는 대부분 모재부에서 파단이 발생하고 인장강도

\begin{tabular}{|c|c|c|c|}
\hline $\begin{array}{c}\text { Speed } \\
\text { Current }\end{array}$ & 7 & 9 & 11 \\
\hline 140 & $\begin{array}{c}\text { Hunping } \\
\text { bead }\end{array}$ & $\begin{array}{c}\text { Hunping } \\
\text { bead }\end{array}$ & $\begin{array}{c}\text { Hunping } \\
\text { bead }\end{array}$ \\
\hline 155 & & & $\begin{array}{c}\text { Hunping } \\
\text { bead }\end{array}$ \\
\hline 170 & & & \\
\hline
\end{tabular}

(a) Teaching position $=1$
값이 $410 \mathrm{MPa}$ 이상임을 확인할 수 있었으며 일부 실 험결과에서는 용접부 파단이 관찰되었고, 인장강도 값 은 $330 \mathrm{MPa} \sim 400 \mathrm{MPa}$ 수준으로 모재 파단이 발

\begin{tabular}{|c|c|c|c|}
\hline $\begin{array}{c}\text { Speed } \\
\text { Current }\end{array}$ & 7 & 9 & 11 \\
\hline 140 & $\begin{array}{c}\text { Hunping } \\
\text { bead }\end{array}$ & $\begin{array}{c}\text { Hunping } \\
\text { bead }\end{array}$ & $\begin{array}{c}\text { Hunping } \\
\text { bead }\end{array}$ \\
\hline 155 & & & $\begin{array}{c}\text { Hunping } \\
\text { bead }\end{array}$ \\
\hline 170 & & & \\
\hline
\end{tabular}

(b) Teaching position $=0$

Fig. 5 Results of cross-section bead geometry for MIG welded dissimilar combination, (a) T.P = 1, (b) T.P = 0

Table 4 Results of dimension for bead geometry according to welding parameters

\begin{tabular}{|c|c|c|c|c|c|c|c|c|c|}
\hline \multirow[b]{2}{*}{ Case No. } & \multicolumn{3}{|c|}{ Welding parameter } & \multicolumn{6}{|c|}{ Bead geometry } \\
\hline & Current & Speed & $\begin{array}{l}\text { Teaching } \\
\text { position }\end{array}$ & L1 & L2 & L3 & $\mathrm{L} 4$ & L5 & $\theta$ \\
\hline 1 & 155 & 7 & 1 & 2.01 & 7.01 & 3.34 & 5.51 & 4.24 & 102.3 \\
\hline 2 & 155 & 9 & 1 & 0.89 & 7.66 & 3.65 & 4.69 & 6.03 & 134.1 \\
\hline 3 & 170 & 7 & 1 & 0.32 & 7.85 & 3.87 & 5.76 & 5.28 & 131.1 \\
\hline 4 & 170 & 9 & 1 & 0.62 & 8.05 & 3.88 & 5.47 & 5.71 & 131.1 \\
\hline 5 & 170 & 11 & 1 & 0.48 & 8.77 & 4.13 & 6.30 & 5.69 & 121.9 \\
\hline 6 & 155 & 7 & 0 & 0.60 & 6.96 & 3.49 & 4.56 & 5.36 & 125.9 \\
\hline 7 & 155 & 9 & 0 & 1.03 & 7.23 & 3.43 & 4.52 & 5.55 & 112.6 \\
\hline 8 & 170 & 7 & 0 & 0.85 & 8.30 & 3.79 & 4.82 & 6.53 & 134.2 \\
\hline 9 & 170 & 9 & 0 & 0.59 & 7.57 & 3.65 & 5.12 & 5.36 & 129.0 \\
\hline 10 & 170 & 11 & 0 & 1.20 & 7.94 & 3.35 & 4.03 & 6.60 & 121.6 \\
\hline
\end{tabular}

Table 5 Results of tensile strength and fracture location

\begin{tabular}{|c|c|c|c|c|c|c|c|c|c|c|c|}
\hline \multirow{3}{*}{$\begin{array}{c}\text { Case No. } \\
1\end{array}$} & \multicolumn{3}{|c|}{ Welding parameter } & \multicolumn{8}{|c|}{ Tensile strength $(\mathrm{MPa}) /$ Fracture location } \\
\hline & \multirow{2}{*}{$\frac{\text { Current }}{155}$} & \multirow{2}{*}{$\frac{\text { Speed }}{7}$} & $\begin{array}{l}\text { Teaching } \\
\text { position }\end{array}$ & \multicolumn{2}{|c|}{ Test 1} & \multicolumn{2}{|c|}{ Test 2} & \multicolumn{2}{|c|}{ Test 3} & \multicolumn{2}{|c|}{ Test 4} \\
\hline & & & \multirow{5}{*}{1} & 419 & B.M & 420 & B.M & 420 & B.M & 417 & B.M \\
\hline 2 & 155 & 9 & & 330 & W.M & 353 & W.M & 378 & W.M & 345 & W.M \\
\hline 3 & 170 & 7 & & 428 & B.M & 423 & W.M & 427 & B.M & 427 & B.M \\
\hline 4 & 170 & 9 & & 419 & B.M & 420 & B.M & 419 & B.M & 360 & W.M \\
\hline 5 & 170 & 11 & & 418 & B.M & 420 & B.M & 409 & B.M & 337 & W.M \\
\hline 6 & 155 & 7 & \multirow{5}{*}{0} & 275 & W.M & 286 & W.M & 377 & W.M & 307 & W.M \\
\hline 7 & 155 & 9 & & 235 & W.M & 288 & W.M & 267 & W.M & 314 & W.M \\
\hline 8 & 170 & 7 & & 422 & B.M & 401 & W.M & 312 & W.M & 306 & W.M \\
\hline 9 & 170 & 9 & & 427 & W.M & 368 & W.M & 336 & W.M & 361 & W.M \\
\hline 10 & 170 & 11 & & 279 & W.M & 310 & W.M & 255 & W.M & 391 & W.M \\
\hline
\end{tabular}




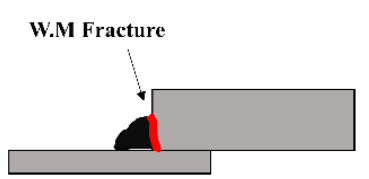

(a)

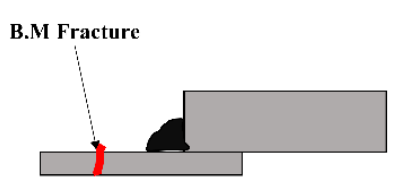

(b)
Fig. 6 Schematic of fracture location after tensile strength test, (a) weld metal fracture, (b) base metal fracture

생한 인장강도 값 대비 소폭 감소함을 확인하였다. 반 면에, T.P가 0인 Case 6 10의 경우 대부분 용접 부에서 파단이 발생하였으며, 인장강도 역시 $200 \mathrm{MPa}$ $300 \mathrm{MPa}$ 수준으로 모재에서 파단이 발생한 조건 대 비 현저하게 인장강도 값이 낮은 것을 확인하였다.

아크용접시 용접부 인장강도에 영향을 끼치는 주요 인자로는 비드 형상이 대표적이며, 접합된 면적이 직접 적인 요인으로 알려져 있다 ${ }^{13,14)}$. Fig. 5 와 Table 5 의 결과를 종합해보면, 용접 변수 중 T.P의 변화에 따라 파단위치와 인장강도 값이 변화함을 예상할 수 있으며, 용접부 파단이 발생한 용접조건의 경우 파단의 위치가 $\mathrm{SS} 400$ 과 용접부의 계면에서 발생하였기 때문에 비드 형상 인자 중 SS400와 용접재료의 접합부 길이를 의 미하는 Table 4 의 L4가 영향을 미칠 수 있을 것으로 사료된다. SUS439와 용접재료의 접합부 길이인 L5 역시 인장강도에 영향을 끼치는 주요인자로 판단되나, 그 값이 대부분 L4보다 동등이상으로 형성되어 있어서 대부분의 파단은 $\mathrm{SS} 400$ 과 용접재료가 접합되는 영역 에서 파단이 발생한 것으로 판단된다. Table 4 와 Table 5의 결과를 통해 파단이 발생한 조건과 L4 값 을 비교해 보면, $\mathrm{L} 4$ 의 길이가 $5.5 \mathrm{~mm}$ 이상임을 확인 하였고 L4가 $4.8 \mathrm{~mm}$ 이상인 경우는 모재파단 혹은 용접부 파단, 그 이하는 용접부 파단이 발생하는 것을 확인하였다. 즉, $\mathrm{L} 4$ 의 길이가 상부 모재 두께인 $8 \mathrm{~mm}$ 중 $68 \%$ 이상의 면적이 접합되어야만 용접부 파단이 아 닌 모재 파단이 발생할 수 있는 것으로 사료된다. 3.2 항부터는 실제 실험으로 얻은 비드 형상인자들의 값을 활용하여 기초적인 선형 회귀분석을 통해 비드 형상인 자를 결정짓는 용접변수가 무엇이며, 본 연구를 통해 얻은 인장강도 및 파단위치와 비드 형상인자와의 관계 성을 확인하고자 하였다.

\section{2 회귀분석을 통한 상관관계 도출}

먼저, 용접부 비드 형상인자별 치수 변화에 영향을 끼치는 용접변수(독립변수)을 확인하기 위해 회귀분석 중 주효과도 분석을 수행한 결과를 Fig. 7에 나타내었 다. 본 실험조건 범위에서 대부분의 용접부 비드 치수

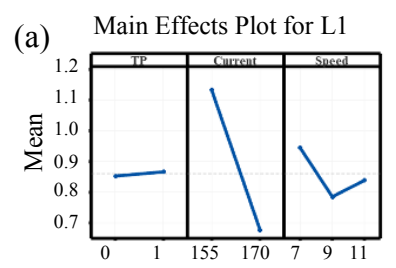

(b) Main Effects Plot for L2
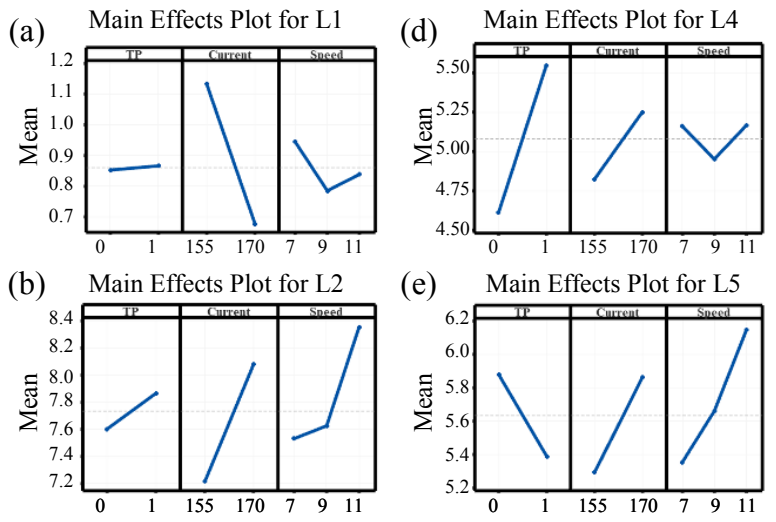

(e)
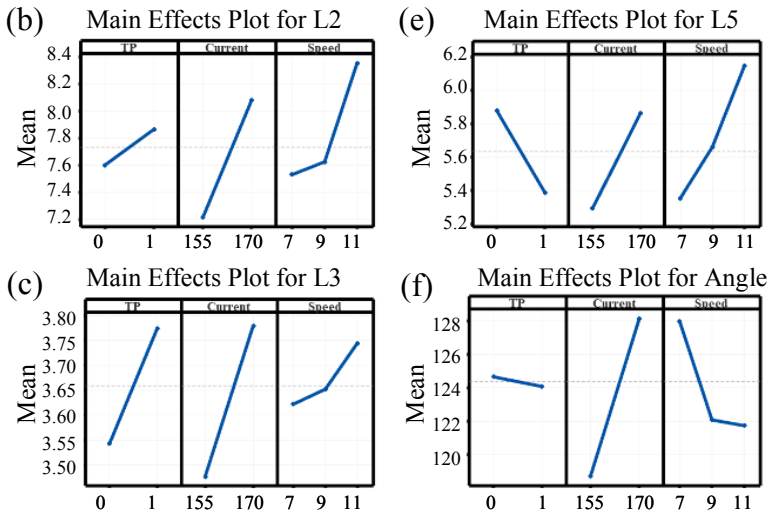

Fig. 7 Main effect of input variable on each dimension of bead geometry, (a) L1, (b) L2, (c) L3, (d) L4, (e) L5, (f) $\theta$

값은 용접전류 또는 용접속도 변화에 따라 비례하거나 반비례하는 경향을 보였다. 그러나 L4는 용접전류 및 용접속도보다 T.P 변화에 따라 영향 받는 것을 확인하였 으며 T.P가 하부판재에서 상부판재 두께 방향으로 $1 \mathrm{~mm}$ 떨어질수록 $\mathrm{L} 4$ 의 길이가 증가하는 경향을 관찰하였으 며 이는 Table 4의 결과와도 일치함을 확인하였다. T.P 가 1 일 때 $\mathrm{L} 4$ 의 길이가 증가하는 원인은 용접시 아크 열원이 상부판재에서 초기 발생하여 상부 판재를 용융 시키고 중력방향으로 용융풀이 흐르기 때문에 L4의 영 역이 더 넓어지는 것으로 사료된다. 그 외의 비드 형상 인자들은 T.P의 수준 변화보다 용접전류나 용접속도 변화에 더 큰 영향을 미치는 것으로 판단된다. 이는 일 반적으로 비드 형상을 결정짓는 주요인자가 용접전류와 용접속도이나, 본 연구에서는 두께 비에 의한 T.P를 변수로 선정하여 L4의 경우만 T.P의 영향을 더 받았 기 때문인 것으로 예측할 수 있다.

다음은 용접부 비드 형상인자와 인장강도 값의 상관 관계를 도출하기 위해 회귀분석 방법 중 적합선 그림 결과를 Fig. 8에 나타내었다. 본 실험조건 범위 안에 서는 L4를 제외한 모든 치수 값과 인장강도간의 상관 관계는 $\mathrm{P}$-값이 0.05 이상으로 인장강도 값의 변화에 관계가 높지 않은 것을 판단할 수 있었으며, $\mathrm{L} 4$ 의 경 우는 P-값이 0.001로 유효한 수치로써 $\mathrm{R}^{2}$ 도 $75 \%$ 이상의 높은 수치를 나타내었다. 즉 L4와 인장강도 값 은 일반 선형적 관계가 있는 것으로 예상할 수 있다. 이는 앞서 실제 용접부 비드 형상에도 언급하였듯이, 

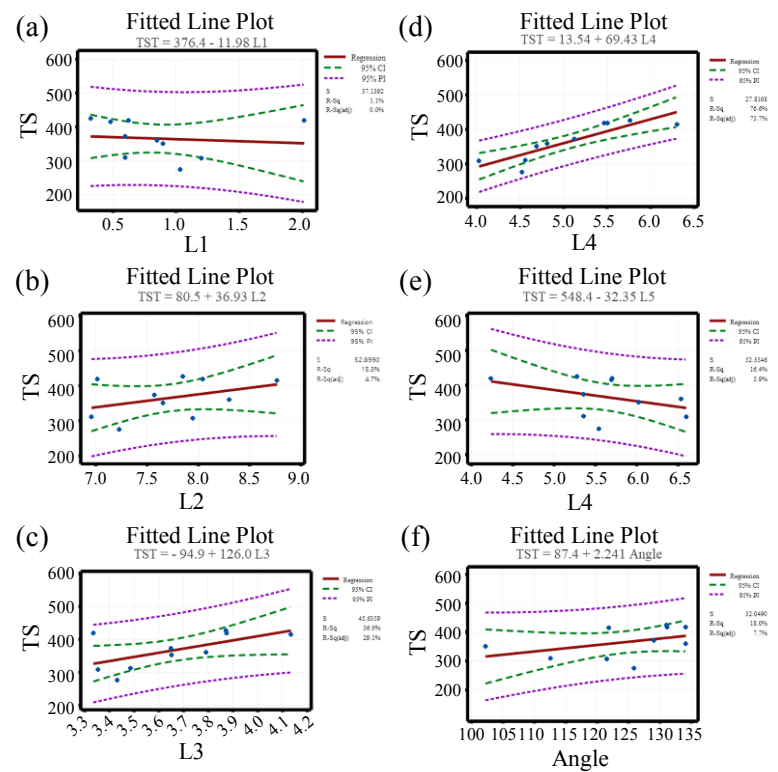

Fig. 8 Fitted line plot of each dimension of bead geometry affected the tensile strength, (a) L1, (b) L2, (c) L3, (d) L4, (e) L5, (f) $\ominus$

인장강도에 영향을 미칠 수 있는 접합부 인자인 $\mathrm{L} 4$, $\mathrm{L} 5$ 중 $\mathrm{L} 5$ 의 길이가 $\mathrm{L} 4$ 의 길이보다 동등 이상이기 때 문에 $\mathrm{L} 4$ 의 영향이 더 크기 때문인 것으로 사료된다. 회귀분석을 통해 실제 용접부 비드 형상인자와 인장강 도 및 파단위치간의 상관관계를 분석한 결과 $\mathrm{L} 4$ 와 인 장강도 값의 관계가 다른 형상인자 대비 선형적인 관계 가 있음을 확인하였다. 실제 인장강도결과와 회귀분석 을 통해 L4 기준 상부 모재 두께인 $8 \mathrm{~mm}$ 대비 $68 \%$
이상인 $5.6 \mathrm{~mm}$ 를 기준으로 파단 위치가 변화함을 검 증하고 그 이유를 고찰하고자 ANSYS 해석을 수행하 였다.

\subsection{ANSYS 해석을 통한 비드와 인장강도 상관관계 검증}

인장강도 및 파단위치와 비드 형상인자 중 $\mathrm{L} 4$ 와의 관계를 검증하기 위해 ANSYS 시뮬레이션을 수행하였 다. 시뮬레이션 수행 시 변수로는 L4 길이만을 단독 변수로 하여, $4 \mathrm{~mm}$ 부터 $6.4 \mathrm{~mm}$ 까지 $0.8 \mathrm{~mm}$ 간격 으로 총 4 가지의 Case를 선정하고 그 외 용접부 비드 형상인자는 고정 값으로 선정하였다. ANSYS 시뮬레 이션을 활용하여 L4 변화에 따른 파단 위치 변화 결과 를 Fig. 9와 Table 6에 나타내었다. 먼저 하부 판재 기준으로 보면 Case 1과 Case 2는 변위를 $0.03 \mathrm{~mm}$ 이상으로 이동 시 인장강도가 하부 판재의 최대 인장강 도인 $455 \mathrm{MPa}$ 에 도달하였으며 Case 3과 4의 경우는 $0.03 \mathrm{~mm}$ 미만에서 최대 인장강도인 $455 \mathrm{MPa}$ 에 도 달한 것을 확인하였다. 상부판재 기준으로는 모든 Case 에서 $0.06 \mathrm{~mm}$ 의 변형이 발생해야 최대 인장강도 값 에 도달함을 확인하였고 용접부의 경우 Case 1, 2 는 $0.03 \mathrm{~mm}$ 미만에서 그리고 case 3, 4의 경우는 0.03 $\mathrm{mm}$ 를 초과할 경우 용접부 최대 인장강도인 $392 \mathrm{MPa}$ 에 도달하였다. 각 부위별 결과를 취합해 보면 Case 1, 2는 용접부에서 가장 짧은 변위를 Case 3,4 에서 는 하부 판재에서 가장 짧은 변위 값을 나타낸 것으로

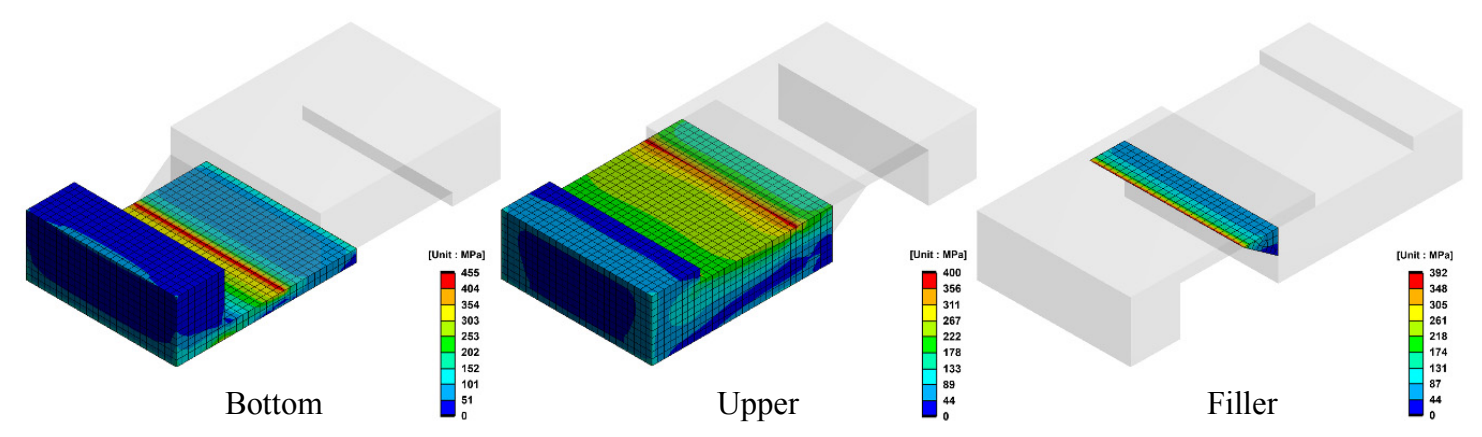

Fig. 9 Representative image of minimum stress and displacement of each material after tensile ANSYS simulation

Table 6 Value and location of minimum displacement for fracture according to changes L4 dimension

\begin{tabular}{|c|c|c|c|c|}
\hline & \multicolumn{2}{|c|}{ Minimum displacement for fracture [mm] } & \multirow{2}{*}{$\begin{array}{c}\text { Initial fracture } \\
\text { location }\end{array}$} \\
\cline { 2 - 4 } & Bottom (SUS 439) & Top (SS400) & Filler (SF-436) & Filler (SF436) \\
\hline CASE 1 $(\mathrm{L} 4=4.0 \mathrm{~mm})$ & 0.0308 & 0.0663 & 0.0271 & Filler (SF436) \\
\hline CASE 2 $(\mathrm{L} 4=4.8 \mathrm{~mm})$ & 0.0303 & 0.0667 & 0.0280 & Bottom (SUS 439) \\
\hline CASE 3 $(\mathrm{L} 4=5.6 \mathrm{~mm})$ & 0.0299 & 0.0671 & 0.0302 & Bottom (SUS 439) \\
\hline CASE 4 $(\mathrm{L} 4=6.4 \mathrm{~mm})$ & 0.0297 & 0.0674 & 0.0312 & \\
\hline
\end{tabular}

본 논문은 독자의 이해를 돕기위하여 영문논문을 국문으로 번역하여 게재한 논문입니다. 저자는 본 논문으로 연구업적과 같은 실적에 중복으로 지원받거나 인정받을 수 없음을 알려드립니다. 
확인하였다. 즉, $\mathrm{L} 4$ 가 $4.8 \mathrm{~mm}$ 이하인 Case 1 과 2 의 경 우 용접부에서 먼저 파단이 발생하며, $\mathrm{L} 4$ 가 $5.6 \mathrm{~mm}$ 이상인 Case 3 과 4 의 경우 하부 판재에서 먼저 파단 이 발생할 것으로 판단할 수 있다. ANSYS 해석을 통 해 L4 길이와 인장강도 및 파단 위치의 상관관계를 해 석한 결과 $\mathrm{L} 4$ 가 $4.8 \mathrm{~mm}$ 이하면 용접부 파단이 발생하 고 L4가 $5.6 \mathrm{~mm}$ 이상인 경우 모재 파단이 발생하였기 때문에 임계 $\mathrm{L} 4$ 길이는 $4.8 \mathrm{~mm} \sim 5.6 \mathrm{~mm}$ 인 것으 로 사료된다.

\section{4. 결 론}

두께 비가 4:1 인 $\operatorname{SS} 400$ (8 t) 와 SUS 439 (2 t) 이종조합의 $\mathrm{MIG}$ 용접에서 용접 비드와 인장강도간의 상관관계를 회귀 분석 및 ANSYS 해석에 관한 연구결 과는 다음과 같다

1) T.P가 하부판재에서 $1 \mathrm{~mm}$ 인 경우 $400 \mathrm{MPa}$ 이상을 만족하는 조건이 도출되었으며 T.P가 0인 경우 용접부에서 파단이 발생하며, 인장강도 불만족하였다

2) L4 길이와 인장강도와의 상관관계 분석을 위한 회귀 분석한 결과 주효과도를 통해 비드 형상인자중 L4 길이는 T.P 변화에 따라 영향을 가장 많이 받음을 확인하였으며 적합성그림 분석을 통해 L4의 변화가 인 장강도 변화에 가장 큰 영향을 미치는 것을 확인하였다.

3) ANSYS 해석을 통해 L4 길이와 인장강도 및 파 단 위치의 상관관계를 해석한 결과 L4가 $4.8 \mathrm{~mm}$ 이 하인 경우 용접부에서 파단이 발생하며 L4가 $5.6 \mathrm{~mm}$ 이상인 경우 모재에서 파단이 발생하였기에 파단 위치 의 변화 임계 $\mathrm{L} 4$ 길이는 $4.8 \mathrm{~mm} \sim 5.6 \mathrm{~mm}$ 인 것 으로 사료된다.

\section{후 기}

본 논문은 2020년도 정부(산업통상자원부)의 재원으 로 광역협력권산업육성(NK200035)의 지원을 받아 수 행되었습니다.

ORCID: Jae Won Km: https://orcid.org/0000-0001-6984-3282 ORCID: Changwook Ji: http://orcid.org/0000-0002-5158-5243

\section{Reference}

1. M. K. Khair, A Review of Diesel Particulate Filter Technologies, SAE Technical Paper Series (2003). https://doi.org/10.4271/2003-01-2303

2. K. Kimapong, S. Triwanapong, Influence of Gas Metal Arc Welding Parameter on Lap Joint Properties of SS400 Carbon Steel and SUS304 Stainless Steel, Key
Eng. Mater. 789 (2018) 110-114.

http://doi:10.4028/www.scientific.net/kem.789.110

3. N. Arivazhagan, S. Singh, S. Prakash, and G. M. Reddy, Investigation on AISI 304 austenitic stainless steel to AISI 4140 low alloy steel dissimilar joint by gas tungsten arc, electron beam and friction welding, Mater. Des. 32 (2011) 3036-3050.

4. S. Wang, Q. Ma, and Y. Li, Characterization of microstructure, mechanical properties and corrosion resistance of dissimilar welded joint between 2205 duplex stainless steel and 16MnR, Mater. Des. 32 (2011) 831-837.

5. I. Hajiannia, M. Shamanian, and M. Kasiri, Microstructure and mechanical properties of AISI 347 stainless steel/ A335 low alloy steel dissimilar joint produced by gas tungsten arc welding, Mater. Des. 50 (2013) 566-573.

6 . KS B 0802, Method of tensile test for metallic materials, Korea Standard (KS) (2003).

7. I. Hwang, D. Y. Kim, G. Jeong, M. Kang, D. Kim, and Y. M. Kim, Effect of Weld Bead Shape on the Fatigue Behavior of GMAW Lap Fillet Joint in GA $590 \mathrm{MPa}$ Steel Sheets, Met. 7 (2017) 399-410. https://doi.org/10.3390/met7100399

8. D. Y. Kim, I. Hwang, G. Jeong, M. Kang, D. Kim, J. Seo, and Y. M. Kim, Effect of Porosity on the Fatigue Behavior of Gas Metal Arc Welding Lap Fillet Joint in GA $590 \mathrm{MPa}$ Steel Sheets, Met. 8 (2018) 241-253. https://doi.org/10.3390/met8040241

9. J. S. Jung, H. K. Lee, and Y. W. Park, Prediction of Tensile Strength for Plasma-MIG Hybrid Welding Using Statistical Regression Model and Neural Network Algorithm, J. Weld. Join. 34(2) (2016) 67-72.

https://doi.org/10.5781/JWJ.2016.34.2.67

10. S. H. Jung, D. Y. Lee, B. U. Kim, and M. K. Lee, A Study for TIG Welding Optimization on Bead Shape of A6061 Alloy Sheet Using DOE, J. Weld. Join. 36(3) (2018) 31-37. https://doi.org/10.5781/JWJ.2018.36.3.5

11. S. W Lee and J. W. Kim, Selecting Optimum Conditions for SPR Processing of High Tension Plates and Aluminum Sheets Using Response Surface Methodology, J. Weld. Join. 37(4) (2019) 339-346. https://doi.org/10.5781/JWJ.2019.37.4.8

12. D. H. Choi and J. H. Shin, Weld Shape Analysis using Central Composite Design in the Laser Welding of Aluminum Alloys, J. Weld. Join. 38(5) (2020) 502-507. https://doi.org/10.5781/JWJ.2020.38.5.10

13. M. P. Groover, Fundamentals of Modern Manufacturing: Materials, Processes, and Systems, 3ed., John Willey \& Sons (Asia) Pte. Ltd., Singapore (2007).

14. J. W. Kim, N. H. Kang, Y. D. Park, D. C. Kim, and M. J. Kang, Effect of Strength Grades of Dual Phase Steels on Failure Location and Joint Efficiency of GMAW Lap Joints, Korean J. Met. Mater. 52(4) (2014) 319-326. https://doi.org/10.3365/KJMM.2014.52.4.319 